\title{
Why is the infectious stage of syphilis prolonged?
}

\author{
D. J. M. WRIGHT* AND A. S. GRIMBLE \\ From the Departments of Medicine and Venereology, Guy's Hospital, London
}

There are two main stages in the progress of syphilis: the infectious stage, followed by the non-infectious stage. This distinction between an early infectious and a late stage is useful for the clinician and indispensable when considering the immunological response. It is clearly seen when the treponeme of syphilis is re-inoculated into patients who have already acquired a syphilitic infection; the response then varies according to whether the patient is in the infectious or the non-infectious stage of the disease. In the patient with early treated syphilis, re-infection results which clinically mimics the early disease, having a chancre or exanthematous lesion at the point of entry; if the disease has passed into the late noninfectious stage, when hypersensitivity to the treponeme and its antigens develops, a gumma may form at the site of inoculation (Magnuson, Thomas, Olansky, Kaplan Di Mello, and Cutler, 1956). Thus we see that the reaction of the host to re-inoculation is independent of the strain of organism but is related to the nature of the body's response. It is contended that the immunological reaction in early infectious syphilis is one which reveals a partial inhibition of the cellular response to $T$. pallidum but not of the humoural response. This lack of cell-mediated response may possibly account for the infectious nature of the early lesion, for the persistence of the spirochaetes in the tissues, and hence for the nature of the late disease.

\section{The immune response in syphilis}

Eberson (1921) found that serum from patients with syphilis prevented the development of a syphiloma in experimental animals inoculated with emulsions of treponemes (see also Turner, 1939; Turner, Fleming, and Brayton, 1939). These workers thereafter attributed the absence of infectious lesions in the late stages of syphilis to the protective effect of syphilitic serum. Antibodies, particularly immobilisins, were subsequently considered to be the responsible agents (Nelson and Mayer, 1949). Later, Turner and
Hollander (1957) claimed that neither the appearance of immobilisins nor that of any other antibodies was related to the resistance of infection in man, as they failed to eliminate all the spirochaetes. In syphilis, protection against infection, if Turner and Hollander are correct, is related to the development of cellmediated (tissue) immunity (Chesney, 1926).

Laird and Thorburn (1966) induced delayed tuberculin-type skin responses in patients with late acquired or congenital syphilis by the repeated intradermal inoculation of material from rabbit syphilitic testes ('luotest'). However, despite the ease with which this cell-mediated skin reaction could be induced in man, it is rarely found in the infectious phase of clinical syphilis. The test is usually negative when extracts of the 'luotest' are used as antigen (Table I).

TABLE I Skin testing for delayed hypersensitivity in early infectious syphilis

\begin{tabular}{|c|c|c|c|c|}
\hline \multirow{2}{*}{$\begin{array}{l}\text { Form of } \\
\text { syphilis }\end{array}$} & \multirow[b]{2}{*}{ No. of cases } & \multicolumn{2}{|c|}{ Reaction } & \multirow[b]{2}{*}{ Author ${ }^{\mathrm{a}}$} \\
\hline & & + & - & \\
\hline 1. Chancre & $\begin{array}{l}52 \\
32 \text { (all WR neg.) } \\
26\end{array}$ & $\begin{array}{l}0 \\
4 \\
1\end{array}$ & $\begin{array}{l}52 \\
28 \\
25\end{array}$ & $\begin{array}{l}\text { Klausner } \\
\text { Muiller and } \\
\text { Stein } \\
\text { Noguchi }\end{array}$ \\
\hline 2. Rash & $\begin{array}{l}620 \\
113 \\
12 \text { (untreated) } \\
37 \text { (treated) }\end{array}$ & $\begin{array}{r}0 \\
3 \\
\\
2 \\
26\end{array}$ & $\begin{array}{r}620 \\
110 \\
10 \\
11\end{array}$ & $\begin{array}{l}\text { Klausner } \\
\text { Müller and } \\
\text { Stein } \\
\text { Noguchi } \\
\text { Noguchi }\end{array}$ \\
\hline 3. Malignant & 10 & 6 & 4 & Klausner \\
\hline
\end{tabular}

a Authors and references from Planner (1929).

This 'anergy' in the early infectious stage disappears with treatment or with the natural progression of the disease. In the late stage, anti-syphilitic treatment has no effect on the existing positive luotest reactions (Table II, overleaf). The only condition in late syphilis where negative skin tests have been consistently recorded is paresis (GPI) (Boss and Ditlevsen, 1913). The resemblance here to the immunological findings in early syphilis is striking. There is an abundance of treponemes in the cerebral tissue in paresis (WorsterDrought, 1940) and, moreover, high antibody titres 
TABLE II Skin testing for delayed hypersensitivity in late syphilis

\begin{tabular}{|c|c|c|c|c|}
\hline \multirow{2}{*}{$\begin{array}{l}\text { Form of } \\
\text { syphilis }\end{array}$} & \multirow[b]{2}{*}{ No. of cases } & \multicolumn{2}{|c|}{ Reaction } & \multirow[b]{2}{*}{ Author ${ }^{\mathrm{a}}$} \\
\hline & & + & - & \\
\hline \multicolumn{4}{|c|}{ 1. Late latent and late syphilis including gumma } & \multirow{4}{*}{$\begin{array}{l}\text { Klausner } \\
\text { Müller and } \\
\text { Stein } \\
\text { Noguchi }\end{array}$} \\
\hline 'tertiary' & 142 & 128 & 14 & \\
\hline 'tertiary' & 47 & 45 & 2 & \\
\hline $\begin{array}{l}\text { 'tertiary' } \\
\text { (Treated and un }\end{array}$ & $\begin{array}{l}59 \\
\text { treated cases beh }\end{array}$ & $\begin{array}{r}57 \\
\text { have s }\end{array}$ & $\begin{array}{c}2 \\
\text { ilarly) }\end{array}$ & \\
\hline \multirow[t]{3}{*}{ 2. 'Cerebrospinal' } & (meningovascular & & & \multirow{3}{*}{$\begin{array}{l}\text { Müller and } \\
\text { Stein } \\
\text { Noguchi }\end{array}$} \\
\hline & 12 & 4 & 8 & \\
\hline & 10 & 5 & 5 & \\
\hline \multirow{2}{*}{ 3. Paresis (GPI) } & & & & \multirow[b]{2}{*}{$\begin{array}{l}\text { Müller and } \\
\text { Stein }\end{array}$} \\
\hline & 40 & 2 & 38 & \\
\hline \multirow[t]{2}{*}{ 4. 'Metalues' } & & & & \multirow[b]{2}{*}{$\begin{array}{l}\text { Klausner } \\
\text { Noguchi }\end{array}$} \\
\hline & $\begin{array}{l}55 \\
72\end{array}$ & $\begin{array}{r}0 \\
45\end{array}$ & $\begin{array}{l}55 \\
27\end{array}$ & \\
\hline \multirow[t]{2}{*}{ 5. Congenital } & & & & \multirow[b]{2}{*}{ Klausner } \\
\hline & 26 & 26 & $\mathbf{0}$ & \\
\hline \multirow[t]{3}{*}{ Controls } & 450 & $\mathbf{0}$ & 450 & \multirow{3}{*}{$\begin{array}{l}\text { Klausner } \\
\text { Müller and } \\
\text { Stein } \\
\text { Noguchi }\end{array}$} \\
\hline & 140 & 3 & 137 & \\
\hline & 200 & o & 200 & \\
\hline
\end{tabular}

a Authors and references from Planner (1929)

are found in the serum and cerebrospinal fluid Stokes, Beerman, and Ingraham, 1944).

Evidence for the depression of cell-mediated immunity in lymphoid tissues

This initial inhibition of the immune response in early infectious syphilis is reflected by the finding of depletion of lymphocytes in the paracortical (thymus dependent) areas of lymph-nodes (Figure). It may be seen that the depletion occurs in the presence of primary sores as well as in the secondary stage (data from Turner and Wright, 1973).

The lesser extent of depletion observed in the syphilitic lymph-nodes, obtained in recent years from adults with infectious syphilis, contrasts sharply with the very marked lymphocyte depletion that occurred around the splenic follicular arteries in infants dying of congenital syphilis $\mathbf{3 0}$ or more years ago (Hellman, 1921). This contrast in part reflects the milder nature of acquired syphilis, especially today. In our series, depletion of the white pulp was noted in 24 out of 39 spleens from infants dying of congenital syphilis (Table III) (see also Paris and Salomon, 1904). This change was found in only two out of twenty spleens from infants dying of acute, non-syphilitic infections $(P<\cdot 005)$. Comparable diminution of the thymusdependent areas of the spleen, that is, the white pulp, was found experimentally following inoculation
TABLE III Lymphocyte depletion in spleen follicles of infants with congenital syphilis, by age

\begin{tabular}{|c|c|c|c|}
\hline \multirow{2}{*}{$\begin{array}{l}\text { Age } \\
\text { (mths) }\end{array}$} & \multicolumn{3}{|c|}{ Degree of depletion } \\
\hline & Gross & Moderate & Minimal \\
\hline $\begin{array}{l}0-2 \\
2-4 \\
4-6 \\
\text { above } 6\end{array}$ & $\begin{array}{l}5 \\
4 \\
3 \\
0\end{array}$ & $\begin{array}{l}7 \\
3 \\
1 \\
1\end{array}$ & $\begin{array}{l}9 \\
4 \\
1 \\
1\end{array}$ \\
\hline Total & 12 & 12 & 15 \\
\hline
\end{tabular}

Levene, Wright, and Turk, 1971

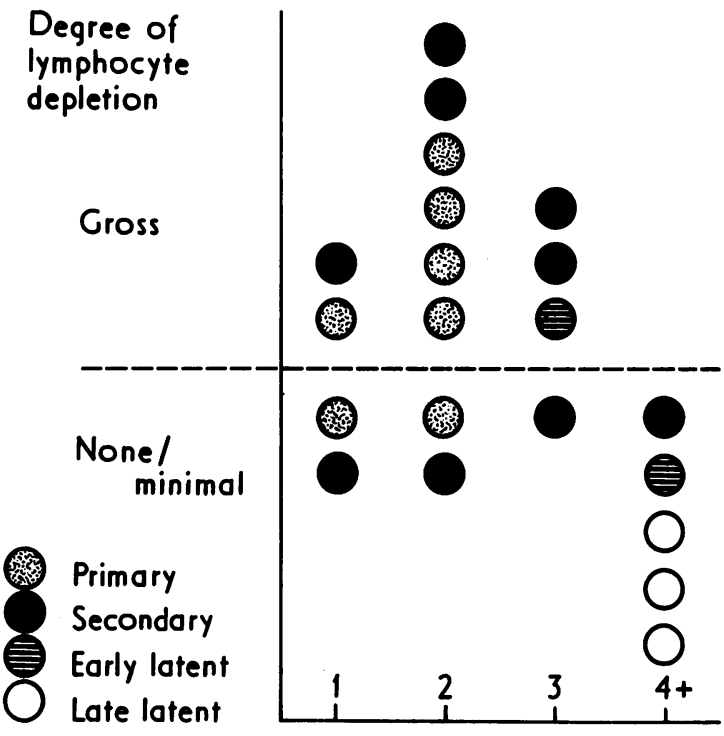

Duration of syphilis (months)

FIGURE Lymphocyte depletion of paracortical areas of lymph nodes in untreated syphilis

of $T$. pallidum into neonatal rabbits (Festenstein, Abrahams, and Bokkenheuser, 1967); control rabbits of the same age failed to show such changes.

It is hard to explain the prolonged depression of cell-mediated responses on any basis other than active suppression of cell-mediated immunity. Certainly, the period of retarded development of cellmediated immunity is too long to be explained simply by delay; especially in view of the rapidity with which a delayed syphilitic skin response can be induced (Laird and Thorburn, 1966).

\section{Evidence from skin tests}

In early infectious syphilis, skin testing with syphilitic antigens was usually negative (Wright and Grimble, unpublished observations), whereas a large selection of non-syphilitic antigens readily produced a positive delayed skin response. 
The non-syphilitic antigens used in the series of tests reported here were: Candida (Bencard), Trichophyton (Bencard), mumps (Eli Lilly), old tuberculin (Evans Medical) $1: 1000$, and varidase (Lederle); a saline control was also incorporated in the experiment. To assess the response in syphilis, the 'luotest' with the appropriate testicular extract, as a control, was also used. This particular antigen was prepared as described by Marshak and Rothman (1951) but with the formalin removed by dialysis against buffered saline. It was found that at least one of the non-syphilitic antigens evoked a positive response in all patients with early syphilis. There were fifteen patients in the primary and 33 in the secondary stage with age-matched controls. The 'luotest' elicited a positive response in only ten out of the 48 patients with early syphilis, and in none of the fifty normal patients.

Laymon (1934) found that a positive Mantoux reaction occurred with the same frequency in patients with secondary syphilis as in other patients. It would seem, from this evidence also, that some overriding specific anergy to syphilitic antigens probably exists at this stage.

\section{Suggested mechanisms for the incomplete immune response}

(i) Plasma factors

One possible cause of the incomplete immune response lies in the plasma factor found by Levene, Turk, Wright and Grimble (1969), which depresses phytohaemagglutinin (PHA) lymphocyte stimulation in infectious syphilis. As PHA stimulates the transformation of the small lymphocyte in culture (Elves, 1972), the inability of PHA to stimulate the lymphocyte in early syphilis suggests a non-specific depression of cellular immunity. This was not related to any abnormality of the lymphocyte in syphilis, such as occurs in reticulosis and other conditions (Willems, Melnick, and Rawls, 1969; Oppenheim, Blaese, and Waldmann, 1970), since lymphocytes from patients with early syphilis transformed normally in response to PHA in non-syphilitic plasma. The plasma factor had different physical properties to antibody (Levene and others, 1969). Additional evidence for the existence of an, at best, weak specific cell-mediated immunity in infectious syphilis lies in the detection of macrophage stimulatory but not inhibitory lymphokines, using Reiter protein antigen. (Fulford and Brostoff, 1972).

\section{(ii) Possible role of antigen}

It has been suggested by Henney and Ishizaka (1968) that antigen in the form of immune complexes may suppress the cellular response. They noted that, when such complexes occurred in association with excess of antibody, delayed hypersensitivity in their experimental model was suppressed.
In syphilis we have been unable to demonstrate significant immunoglobulin deposition in the early rashes, in the cases of seven syphilitic patients, using an immunofluorescent tracing technique. This finding is an additional reason for doubting that Type III (Coombs and Smith, 1968) hypersensitivity damage occurs, especially as material in two of our patients was obtained during a Herxheimer reaction (Wright, 1973). This negative finding confirms the observations of Smith, Bartruff, and Blanchard (1970), who failed to demonstrate insoluble complexes.

With regard to complement depletion, no significant depression of total haemolytic complement, or of C3 component, was found by us in 26 cases of early syphilis or in eighteen cases of congenital syphilis. This further lack of evidence weakens the theory that damage by immune complexes may play a part in the pathogenesis of early syphilis. Nevertheless, in five out of 26 cases of early syphilis, a depression of C4 component occurred, and a similar depression was induced by a Herxheimer reaction in four patients (Wright, 1973). Although endotoxin combining with complement could result in such a reduction in C3, it is unlikely to produce depletion of C4 levels (Lachman, 1972; Gewurz, Shin, and Mergenhagen, 1968).

There remains the possibility, then, that antigenic competition between the many treponemal antigens (Puccinelli, 1951) may cause the divergence between the humoural and cellular responses, and explain the selective cellular immunosuppression or 'split' tolerance found during the infectious phase of syphilis. It appears to be the case in leishmaniasis (Bryceson, Preston, Bray, and Dumonde, 1972), toxoplasmosis and malaria (Strickland, Voller, Pettit, and Fleck, 1972), that antigenic competition enhances antibody titres and depresses delayed hypersensitivity.

\section{(iii) Innate factors}

There is no evidence for a genetic factor in syphilis being responsible for the incomplete immune response. In contrast to leprosy (Newell, 1966; Jamison and Vollum, 1968) there is a universal susceptibility to syphilis, with no genetic or racial variation in the essential features of the clinical disease. Also, it has been found that organ-specific antibody formation, for which there is some familial basis, is much the same in patients with syphilis as in the general population (Wright, Doniach, Lessof, Grimble, and Catterall, 1970).

\section{(iv) Possible role of antibody}

It is feasible that antibody, in certain circumstances, may block the cell-mediated response (Hellström and Hellström, 1970; Bansal and Sjögren, 1971), and 
that in infectious syphilis, suppression of a cellmediated immunity may be so determined. Thus, in syphilitic paresis (GPI) there is a high antibody titre together with a significant absence of delayed hypersensitivity to skin testing (Boas and Ditlevsen, 1913). The appearance of syphilitic paresis itself could be explained by the development of enhancing or blocking antibody allowing a fresh burst of paralytic activity similar to the late relapses observed in experimental malarial infections (Jerusalem, Weiss, and Poels, 1971). Such enhancing antibodies have been shown to suppress allograft rejection in rats (Stuart, Saitoh, and Fitch, 1968) and, in the field of transplantation, promote the growth of tumours (Hellström and Möller, 1965).

In conclusion, we have noted that circulating factors can impair the cellular response and produce the situation found in early syphilis; whether these factors are formed directly in response to antigen or are promoted by antigenic competition, as found in the experimental situation (Fauci and Johnson, 1971; Gershon and Kondo, 1971a, b), is not yet clear. Nevertheless, the significance of this suppression of the cell-mediated limb of the immune response lies in the clinical association of demonstrable spirochaetes, and therefore in infectivity. The gradual diminution of infectivity with the development of cell-mediated immunity in syphilis provides an interesting situation for the study of the manner in which the immune reaction is regulated. Moreover, the use of immunosuppressive agents in syphilis might be valuable in this context, in damping the immune response, and, as in tuberculosis, might prevent further damage taking place while the disease is under treatment. Present studies, however, with the use of steroids in syphilis, have not yielded any certain results (Dunlop, 1970).

\section{Summary}

There are two main stages in syphilis, the infectious and the non-infectious. The immunological reaction in early syphilis is one that shows a partial inhibition of the cell-mediated response, which could account for the persistence of infectiousness and for the ease of demonstrating treponemes in the tissues. The incomplete immune response has been demonstrated by the results of the delayed hypersensitivity skin test and by the finding of a depletion in the areas of lymph nodes closely related to $T$-cell activity and around the splenic follicular arterioles. Several mechanisms for the occurrence of this depression of cell-mediated immunity are suggested. Some experimental evidence is cited and the possible roles of a plasma factor, of antigenic competition, and of antibody in promoting this situation are discussed.
We should like to achowledge the help and advice of Professor M. H. Lessof, Department of Medicine, Guy's Hospital.

\section{References}

Bansal, S. C., and Sjõgren, H. O. (1971) Nature (New Biol.), 233, 76

Boas, H., and Ditlevsen, C. (1913) Arch. Derm., 116, 852

Bryceson, A. D. M., Preston, P. M., Bray, R. S., and Dumonde, P. C. (1972) Clin. exp. Immunol., 10, 305

Chesney, A. M. (1926) Medicine (Baltimore), 5, 463

Coombs, R. R. A., and SMITH, H. (1968) In 'Clinical Aspects of Immunology', ed. P. G. H. Gell and R. R. A. Coombs, 2nd ed., p. 423. Blackwell, Oxford

Dunlop, E. M. C. (1970) Abstr. Wld Med., 44, 241

EBerson, F. (1921) Arch. Derm. Syph. (Chicago), 4, 490

Elves, M. W. (1972) 'The Lymphocyte', 2nd ed., p. 412. Lloyd-Luke, London

FauCI, A. S., and Johnson, J. S. (1971) f. Immunol., 107, 1052

Festenstein, H., Abrahams, C., and Bokkenheuser, V. (1967) Clin. exp. Immunol., 2, 311

Fulford, K. W. M., and Brostoff, J. (1972) Brit. $\mathcal{F}$. vener. Dis., 48, 483

Gershon, R. K., and Kondo, K. (1971a) f. Immunol., 106, 1532

- (1971b) Immunology, 21, 903

Gewurz, H., Shin, H. S., and Mergenhiagen, S. E. (1968) F. exp. Med., 128, 1049

Hellman, T. J. (1921) Beitr. path. Anat., 68, 333

Hellstrõm, K. E., and Hellström, I. (1970) Ann. Rev. Microbiol., 24, 373

- and MölleR, G. (1965) Prog. Allerg., 9, 158

HeNNEy, C. S., and IsHIzAKA, K. (1968) $\mathcal{F}$. Immunol., 101, 896

Jamison, D. G., and Vollum, R. L. (1968) Lancet, 2, 1271

Jerusalem, C., Weiss, M. L., and Poels, L. (1971) $\mathcal{F}$. Immunol., 107, 260

LACHMAN, P. J. (1972) In 'Ontogeny of Acquired Immunity', p. 193. Ciba Foundation Sypmosium, Associated Scientific Publishers, Amsterdam

LAIRD, S. M., and ThORBURN, A. L. (1966) Brit. F. vener. Dis., 42, 119

Laymon, C. W. (1934) Arch. Derm. Syph., 30, 518

LeVene, G. M., WRIGHT, D. J. M., TURK, J. L., and Grimble, A. G. S. (1969) Lancet, 2, 246

-, WrIGHT, D. J. M., and TuRK, J. L. (1971) Proc. roy. Soc. Med., 64, 426

Magnuson, H. J., Thomas, E. W., Olansky, S., Kaplan, B. I., Melio, L. De, and CutLER, J. C. (1956) Medicine (Baltimore), 35, 33

MARShaK, L. C., and Rothman, S. (1951) Amer. f. Syph., 35, 35

Nelson, R. A. (1948) Amer. F. Hyg., 48, 120

and MAYER, M. M. (1949) f. exp. Med., 89, 369

Newelt, K. W. (1966) Bull. Wld Hlth Org., 34, 827

OPPENHEim, J. J., BlaEse, R. M., and WaldmanN, T. A. (1970) f. Immunol., 104, 835 
Paris, A., and Salomon, M. (1904) Arch. Méd. exp., 16, 113

PlanNer, H. (1929) In 'Handbuch der Haut- und Geschlechtskrankheiten', ed. J. Jadassohn, band 15, teil 2, p. 468. Springer, Berlin

Puccinelli, V. A. (1951) Amer. F. Syph., 35, 340

SMITH, E. B., BARTRUFF, J. K., and BLANCHARD, V. (1970) Brit. F. vener. Dis., 46, 426

Stokes, J. H., BeErman, H., and Ingraham, N. R. (1944) 'Modern Clinical Syphilology', 3rd ed., p. 123. Saunders, Philadelphia

Strickland, G. T., Voller, A., Pettit, L. E., and Fleck, D. G. (1972) f. infect. Dis., 126, 54

Stuart, F. P., Saitoh, T., and Fitch, F. W. (1968) Science, 160, 1463

Turner, D. H., and Wright, D. J. M. (1973) F. Path., 110, 305

TURNER, T. B. (1939) f. exp. Med., 69, 867

—, Fleming, W. L., and Brayton, N. L. (1939) f. clin. Invest., 18, 471

and Hollander, L. H. (1957) In 'Biology of the Treponematoses', WHO Monograph Ser. No. 35, p. 163, 218. Wld Hlth Org., Geneva.

Willems, F. T. C., Melnick, J. L., and Rawls, W. E. (1969) Proc. Soc. exp. biol. (N.Y.), 130, 652

WORSTER-Drought, C. (1940) 'Neurosyphilis', p. 129. Bale and Staples, London.
WRIGHT, D. J. M. (1973) M.D. Thesis, London University —, Doniach, D., Lessof, M. H., Grimble, A. G. S., and Catterall, R. D. (1970) Lancet, 1, 740

and GRIMBLE, A. G. S. Unpublished observations.

Pourquoi le stade infectieux de la syphilis se prolonge-t'il?

SOMMAIRE

Il y a deux principaux stades dans la syphilis, l'infectieux et le non-infectieux. Dans la syphilis récente, la réaction immunologique en est une qui montre une inhibition partielle de la réponse immunologique cellulaire, et ceci peut jouer un rôle dans la persistance de l'infectiosité et pour faciliter la découverte des tréponèmes dans les tissus. La réponse immunitaire incomplète a été mise en évidence par les résultats du test cutané d'hypersensibilité retardée et par la constatation d'une déplétion des ganglions en relation étroite avec l'activité des cellules $\mathrm{T}$ et autour des artérioles des follicules spléniques. Plusieurs mécanismes sont évoqués pour expliquer la survenue de cette dépression de l'immunité cellulaire. On cite quelques preuves expérimentales et on discute des rôles possibles d'un facteur plasmatique, de compétition antigénique, et de celui des anticorps pour provoquer ce processus. 